\title{
Effect of amino acids on larval metamorphosis of the polychaete Hydroides elegans
}

\author{
Tao Jin, Pei-Yuan Qian*
}

Department of Biology, Hong Kong University of Science and Technology, Clear Water Bay, Kowloon, Hong Kong SAR

\begin{abstract}
The inductive compounds that are cues for for the settlement and metamorphosis of polychaete Hydroides elegans larvae, isolated from adult homogenate of the same species and leachate of the bryozoan Bugula neritina, are known to be a mixture of amino acids. Here we investigated the toxicity of 20 amino acids on competent larvae. Nine amino acids were found to be toxic at certain concentrations. Subsequently, 12 out of 20 amino acids were assayed for their effect on larval metamorphosis of $H$. elegans. The effects of amino acids were decoupled from possible inductive effects of the bacteria in the bioassay system. The results showed that the amino acid isoleucine had no inductive effect on larval metamorphosis. Two acidic and 9 aliphatic amino acids directly induced larval metamorphosis. The effects of these amino acids were concentration-dependent. Among them, asparagine was the most active amino acid, and induced a high percentage of larval settlement at $1.0 \times 10^{-5} \mathrm{M}$, but became toxic at concentrations higher than $1.0 \times 10^{-4} \mathrm{M}$. The exact mechanisms by which amino acids directly induce larval metamorphosis are still unclear, although we assume that they act by binding to specific receptors and triggering the signal transduction pathway entirely or partially.
\end{abstract}

KEY WORDS: Hydroides elegans $\cdot$ Larval metamorphosis $\cdot$ Chemical cue $\cdot$ Amino acid $\cdot$ Bacteria Resale or republication not permitted without written consent of the publisher

\section{INTRODUCTION}

Most benthic marine invertebrates have a dispersal larval stage in their life cycle (Thorson 1950). Larvae will become competent at settling onto substratum after spending hours, weeks, or months developing in the plankton. On large spatial scales, current patterns, flow velocity, and near-bottom flow dynamics (Butman 1987, 1990, Pawlik \& Butman 1993, Snelgrove et al. 1993, Thiebaut et al. 1996) affect larval settlement and dispersal. On smaller spatial scales, active larval behavior such as substrate rejection or substratum exploration determines the success of larval settlement, particularly when larvae descend to the sea floor. Larvae of many marine invertebrates require specific cues to settle and metamorphose and cues can originate from conspecific or congeneric individuals (Crisp 1984, Pawlik 1992, Rodriguez et al. 1993, Qian 1999), microbial films (Kirchman et al. 1982a, Maki et al. 1989, Lau et al. 2002), sympatric species, food items, habitat (Bryan et al. 1998), and other environmental sources (Pechenik et al. 1995). A variety of chemicals have been suggested to be cues that include juvenile hormones (Biggers \& Laufer 1992, 1996), free fatty acids (Pawlik 1986, Pawlik \& Faulkner 1986, 1988, Jensen et al. 1990), polysaccharides (Kirchman et al. 1982b), protein and small peptides (Jensen \& Morse 1990), amino acids (Harder \& Qian 1999), inorganic ions (Yool et al. 1986, Bryan et al. 1997b, Pechenik \& Qian 1998), and neurotransmitters other than amino acids (Pawlik 1990). However, few natural cues have been isolated and structurally identified.

Identification of larval settlement inducers/inhibitors in marine invertebrates serves as a first step to improve our understanding of the signal transduction pathway involved in settlement and metamorphosis of the target organism. The gregarious distribution patterns of adult populations of marine invertebrates are often caused by either differential post-settlement mortality (Gosselin \& Qian 1997) or differential larval settlement (Qian 1999). 
The aggregate distribution patterns may also be due to aggregate larval settlement near or on conspecifics (Toonen \& Pawlik 1994, Bryan et al. 1997a, Qiu \& Qian 1997). Therefore, species with gregarious settlement patterns often provide model systems for studying interactions between larval settlement and substrata and for the characterization of inducers/inhibitors of larval settlement and metamorphosis. Mechanisms and roles of chemical cues on larvae and the larval receptor systems are studied only for organisms that have been cultured in the laboratory for relatively long periods of time (Pawlik 1992, Qian 1999). Molecules that interfere with signal transduction pathways have now received considerable attention. There are 5 recognized mechanisms by which chemical cues act on larval settlement (Rittschof 1997): (1) toxic effects; (2) altering larval behavior and stimulating metamorphosis; (3) interfering with the transduction pathways leading to metamorphosis; (4) paralyzing larvae; and (5) acting as larval repellants. However, larval receptor systems and signal transduction pathways involved in larval settlement and metamorphosis have not been well documented among marine invertebrates.

Hydroides elegans is a gregarious tube-building polychaete that occurs throughout the Atlantic, Pacific and Indian Oceans. This species colonizes submerged surfaces very rapidly and out-competes other biofouling organisms (Wisely 1958). Larvae of $H$. elegans can quickly settle in response to bacterial films (Lau \& Qian 2001), but can also remain swimming for up to 4.5 mo (pers. obs.). A number of bacterial strains isolated from Hong Kong waters inhibited or induced larval settlement of $H$. elegans (Lau \& Qian 1997). The cues from bacteria were both surface-related and water-soluble (Harder et al. $2002 b)$. Antagonistic effects on induction of larval settlement were observed when highly inductive strains and non-inductive strains were blended into the same bacterial films (Lau \& Qian 1997). Walter et al. (1997) argued that larval settlement patterns of $H$. elegans might be affected by roughness elements of substratum and by hydrodynamics. However, there is substantial evidence that passive settlement due to hydrodynamics alone cannot explain the small-scale distribution of marine invertebrates (Lemire \& Bourget 1996, Bourget \& Harvey 1998). It has been speculated by others working on the same species that a positive larval settlement response to biofilm, coupled with small-flow dynamics, may explain the distribution pattern in nature. We argue strongly that the gregarious distribution patterns of $H$. elegans in Hong Kong waters and in other regions cannot be explained solely by the larval response to bacterial films, because all the submerged marine surfaces are covered with marine biofilm in nature, yet the larvae of $H$. elegans did not settle everywhere. Larval behavior of $H$. elegans is certainly involved in the settlement process.

Larval settlement inducers/inhibitors have been vigorously researched for the purpose of both fundamental research and for fouling control. Hydroides elegans larvae settle in response to aqueous extracts of conspecifics (Bryan et al. 1997b), and the leachate of the sympatric organism Bugula neritina (Bryan et al. 1998). In nature, it was observed that $H$. elegans preferred to settle on $B$. neritina, which indicated that the leachate of the bryozoan is likely to affect larval settlement in the field. The inductive compounds have no negative effects on post-larval-stage growth and development (Qian \& Pechenik 1998). Using a rigid bioassay-guided procedure, Harder \& Qian (1999) isolated and purified bioactive compounds from adult homogenates, gamete suspensions, conditioned seawater of $H$. elegans as well as the naturally released leachate of Bugula neritina. Bioactive compounds consisted of a group of dissolved free amino acids (DFAAs). A mixture of the artificial DFAAs in the given concentrations evoked a similar settlement rate in the bioassay with $H$. elegans larvae as in the original crude samples, indicating that the bioactivity in the purified fractions was exclusively determined by the given DFAAs. Since conditioned seawater with a living $H$. elegans 'colony' induced a similar larval settlement response as did the identified mixture of DFAAs, it was hypothesized that DFAAs released by adults may serve as initial cues to the swimming larvae, and attract competent larvae to the surfaces near the adults. It is possible that the DFAAs also modify the community structure (in both abundance and species composition of bacteria) of the biofilm, making it more attractive to settlement larvae. Beckmann et al. (1999) found that the amino acids could serve as specific nutrients for marine bacteria in the testing dishes and thus promoted a biofilm development which, in turn, triggered the larval settlement. However, they could not exclude possible direct interaction between settling larvae and the amino acids, as a more extensive investigation would be required to fully decouple the effects of amino acids on larvae and that of biofilm.

The current study is a direct follow-up investigation into the triangular relationship between amino acids, biofilm development and settling larvae of Hydroides elegans in experimental dishes in the lab. This study provides a close examination of the effects of 20 amino acids on larval metamorphosis of $H$. elegans and biofilm development. We pose questions regarding whether specific free amino acids can directly induce larval metamorphosis of $H$. elegans, or indirectly induce larval metamorphosis by enhancing bacterial film formation. 


\section{MATERIALS AND METHODS}

Collection of adults and rearing of larvae. Hydroides elegans larvae were obtained using the method described by Bryan et al. (1997b). Adults of $H$. elegans were collected from PVC panels that were submerged at fish farm rafts at $1 \mathrm{~m}$ depth at Long Harbor, Hong Kong $\left(22^{\circ} 24^{\prime} \mathrm{N}, 114^{\circ} 21^{\prime} \mathrm{E}\right)$. The adults were kept in the laboratory with running seawater. In order to obtain gametes, adult worms were placed individually in Petri dishes containing $0.2 \mu \mathrm{m}$ filtered seawater (FSW), and their tubes were gently broken to induce the release of eggs or sperm. The eggs and sperm were mixed to allow fertilization. After $15 \mathrm{~min}$, the embryos were washed twice with FSW to remove excess sperm and transferred to a 21 glass beaker containing FSW. The larvae were fed daily with Isochrysis galbana, and kept at $30^{\circ} \mathrm{C}$ in an incubator until they attained metamorphic competence. Larval competence to metamorphose was tested by exposing the larvae to a well-developed marine natural biofilm (NBF). Competent larvae attached to the surface of dishes within 1 to $2 \mathrm{~h}$ and metamorphosed within $12 \mathrm{~h}$. All settlement and metamorphosis bioassays were performed with 5 to 6 d old larvae after fertilization.

Preparation of test solutions. Twenty free amino acids, all L-isomers, were used in total, and are listed in Table 1. The test solutions were freshly prepared in autoclaved FSW. Each solution was individually distributed into sterile polystyrene Petri dishes (Falcon \#1006) in $4.5 \mathrm{ml}$ aliquots.

Table 1. Amino acids used in bioassay

\begin{tabular}{|lcc|}
\hline Name & Abbreviation & Molecular weight (Da) \\
\hline Alanine & Ala & 71.08 \\
Arginine & Arg & 156.20 \\
Asparagine & Asn & 114.11 \\
Aspartic acid & Asp & 115.09 \\
Cysteine & Cys & 103.14 \\
Glutamine & Gln & 128.14 \\
Glutamic acid & Glu & 129.12 \\
Glycine & Gly & 57.06 \\
Histidine & His & 137.15 \\
Isoleucine & Ile & 113.17 \\
Leucine & Leu & 113.17 \\
Lysine & Lys & 128.18 \\
Methionine & Met & 131.21 \\
Phenyalanine & Phe & 147.18 \\
Proline & Pro & 97.12 \\
Serine & Ser & 87.08 \\
Threonine & Thr & 101.11 \\
Tryptophan & Trp & 186.21 \\
Tyrosine & Tyr & 163.18 \\
Valine & Val & 99.14 \\
& & \\
\hline
\end{tabular}

Toxicity assay. This experiment was designed to examine the effects of amino acids on larval survival. The chemical cues may show inductive effects at low concentrations, but become toxic at high concentrations. For each assay, 5 replicates per treatment were used. Each amino acid was tested from $10^{-3}$ to $10^{-7} \mathrm{M}$, 10 times diluted. Briefly, 20 competent larvae of Hydroides elegans were pipetted into each Petri dish containing a test solution. After $24 \mathrm{~h}$, the number of living larvae was determined under a dissecting microscope.

Larval metamorphosis bioassays. Referring to the results of the toxicity assays, the effects of the nontoxic amino acids on larval metamorphosis were tested. In order to investigate whether the bacterial film development during bioassay affects larval metamorphosis, the amino acid solutions were assayed either in the presence or absence of antibiotics $\left(2.5 \times 10^{-4} \mathrm{M}\right.$ streptomycin and $1.0 \times 10^{-4} \mathrm{M}$ penicillin). The concentrations of amino acid solutions were from $10^{-3}$ to $10^{-5} \mathrm{M}, 10$ times diluted, except for asparagine which was tested from $10^{-5}$ to $10^{-7} \mathrm{M}$. In the larval metamorphosis bioassay, FSW served as a negative and NBF was used as a positive control. Twenty competent larvae were pipetted into each dish containing a test or a control solution. The dishes were incubated at the ambient temperature $\left(30^{\circ} \mathrm{C}\right)$ for $24 \mathrm{~h}$. The number of larvae that had metamorphosed was determined under a dissecting microscope. Larvae that had attached to the surface of the dish or NBF, and had produced tentacles and a calcareous tube were considered to have undergone normal metamorphosis. Some amino acids induced abnormal metamorphosis. Those larvae that did not grow a tube, however, did show evidence of metamorphosis, including loss of the prototroch and development of branchial rudiments.

In order to examine whether bacterial film development on the Petri dish surface affects larval metamorphosis, bacterial densities on the surface of the dishes were determined after observation of larval metamorphosis results. Bacteria were visualized with DNAbinding fluorochrome 4,6-diamidino-2-phenylindole (DAPI, Fluka Chemie). Briefly, the Petri dishes under investigation were emptied and immersed in a $0.22 \mu \mathrm{m}$ filtered solution of $3 \%$ formaldehyde in FSW for $10 \mathrm{~min}$. The dishes were rinsed with distilled water and stained with DAPI at a concentration of $0.5 \mu \mathrm{g} \mathrm{ml}^{-1}$ for $5 \mathrm{~min}$ at room temperature. The mean density of bacteria was determined under a fluorescence microscope (Zeiss Axiophot fluorescence microscope) at 1000x magnification, based on counts of 10 randomly chosen fields of view.

Statistical analysis. Statistical analyses were carried out using an SPSS statistical package. The data of the 
Table 2. Toxic effects of 9 amino acids on competent larvae of Hydroides elegans. Data presented as mean survivorship (\%) \pm SD, $\mathrm{n}=5$. - : all larvae survived after $24 \mathrm{~h}$

\begin{tabular}{|lcccccrrrr}
\hline $\begin{array}{l}\text { Test solution } \\
\text { concentration }\end{array}$ & Arg & Asn & Gln & His & Lys & Met & Phe & Trp & Tyr \\
\hline $10^{-3} \mathrm{M}$ & $0 \pm 0.0$ & $0 \pm 0.0$ & $17 \pm 4.5$ & $0 \pm 0.0$ & $0 \pm 0.0$ & $0 \pm 0.0$ & $0 \pm 0.0$ & $0 \pm 0.0$ & $0 \pm 0.0$ \\
$10^{-4} \mathrm{M}$ & $49 \pm 7.4$ & $25 \pm 3.8$ & $52 \pm 8.4$ & $30 \pm 5.0$ & $2 \pm 2.7$ & $45 \pm 8.7$ & $50 \pm 5.0$ & $0 \pm 0.0$ & $11 \pm 5.5$ \\
$10^{-5} \mathrm{M}$ & - & - & - & - & $25 \pm 6.1$ & $92 \pm 7.6$ & - & $4 \pm 4.2$ & $79 \pm 9.6$ \\
$10^{-6} \mathrm{M}$ & - & - & - & - & - & - & - & $81 \pm 8.9$ & $84 \pm 6.5$ \\
$10^{-7} \mathrm{M}$ & - & - & - & - & - & - & - & - \\
\hline
\end{tabular}

percentages of larval metamorphosis in response to experimental treatments were arcsine-transformed before statistical analysis. The replicates with zero larval metamorphosis were given the value of $1 / 4 \mathrm{n}(\mathrm{n}=$ number of larvae in a single treatment) to improve the arcsine transformation (Zar 1996). The data on bacterial density were not transformed. The normality assumption was verified with Shapiro-Wilk's $W$-test (Shapiro \& Wilk 1965). To analyze the data, 1-way ANOVA followed by Tukey's multiple comparison test ( $\alpha=0.05$ ) was performed. Data that did not meet the normality assumption of parametric analysis were analyzed using nonparametric statistics. This was done by transforming values to ranks and then applying 1-way ANOVA followed by Tukey's multiple comparison test $(\alpha=0.05)$ to the data (Conover \& Iman 1981).

\section{RESULTS}

\section{Toxicity assay}

Out of the 20 amino acids, 9 (Arg, Asn, Gln, His, Lys, Met, Phe, Trp and Tyr; see Table 1 for definitions) showed toxic effects on the competent larvae of Hydroides elegans at certain concentrations (Table 2).
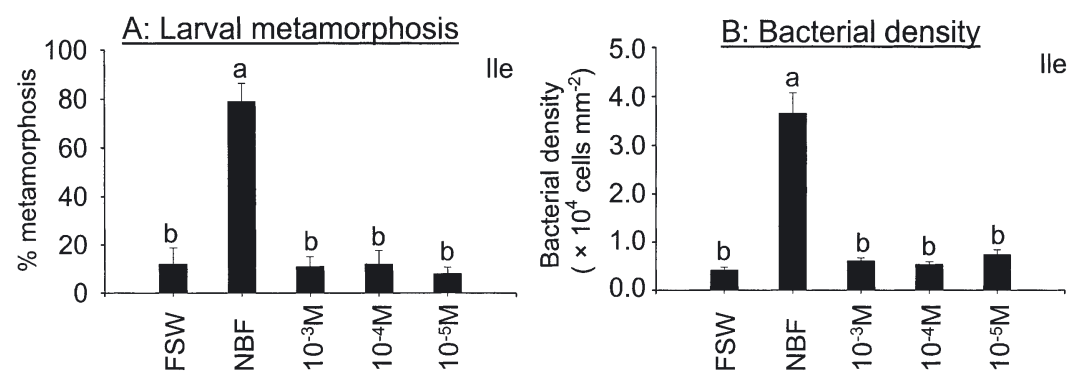

Fig. 1. Hydroides elegans. (A) Percentage of metamorphosed larvae in response to isoleucine (IIe). Data plotted are means + SD of 5 replicates. (B) Bacterial density in test dishes. Data plotted are means + SD based on counts of 10 fields at $1000 \times$ magnification. Data that are significantly different are indicated by different letters above the bars (1-way ANOVA, $\mathrm{p}<0.05)$. FSW: filtered seawater; NBF: marine natural biofilm
Survivorship was dependent on the concentration of the amino acid solutions. Generally speaking, the survivorship of the larvae increased with decreasing concentration of the test solution. These toxic amino acids did not induce larval metamorphosis, with Asn as an exception, since some larvae metamorphosed when exposed to the Asn solution at $1.0 \times 10^{-5} \mathrm{M}$. Therefore, Asn was also tested later in the larval metamorphosis bioassay at lower concentrations than the other amino acids.

\section{Larval metamorphosis bioassay}

When exposed to amino acids, the larval metamorphic response varied substantially with both the types and concentrations of the amino acids being tested. Ten amino acids showed inductive effects on larval metamorphosis, while only one amino acid had no effect.

Of the 11 non-toxic amino acids, Ile had no inductive effect on larval metamorphosis of Hydroides elegans regardless of the concentrations tested. The percentage of larval metamorphosis ranged from 8 to $12 \%$ (Fig. 1). There was no significant difference between treatments and the negative control (1-way ANOVA, $\mathrm{p}<0.05)$. The bacterial density in treatments was also not significantly different from that in the negative control, indicating that this amino acid cannot promote biofilm development either.

Ala, Cys, Gly, Pro, Ser and Val showed similar but significant inductive effects on the larval settlement and partial metamorphosis of Hydroides elegans at certain concentrations in both the absence and the presence of antibiotics (Fig. 2). The bacterial density in the treatments was lower than or similar to that in the negative control, indicating that these amino acids did not promote bacterial film development either. These amino acids induced larval attachment but only induced abnormal metamorphosis. The metamorphosed larvae developed branchial rudiments, but did not 
form complete tentacles, even after several days. They also did not construct calcareous tubes.

Thr and Leu showed similar but significant inductive effects on larval metamorphosis of Hydroides elegans at concentrations of $1.0 \times 10^{-4}$ to $1.0 \times$ $10^{-3} \mathrm{M}$ with the absence of antibiotics (Fig. 3). The bacterial density in treatments was significantly higher than or similar to that in the negative control, indicating that these amino acids have potential in promoting bacterial film development. However, these amino acids also induced a similar percentage of larval metamorphosis with the presence of antibiotics. In both bioassays (with the presence and absence of antibiotics), however, they only induced abnormal metamorphosis.

With the absence of antibiotics, Asn showed an inductive effect on larval metamorphosis of Hydroides elegans at $1.0 \times 10^{-5} \mathrm{M}$ (Fig. 4). The bacterial density at all the concentrations tested was significantly higher than that in the negative control. With the presence of antibiotics, Asn induced the same percentage of larval metamorphosis as in the treatments without antibiotics, and bacterial density here was the same as that in the negative control (Fig. 4). Asn induced normal metamorphosis. The behavior of the larvae in response to Asn was the same as that in response to NBF.

Two acidic amino acids, Glu and Asp, showed similar inductive effects on larval metamorphosis of Hydroides elegans at specific concentrations with the absence of antibiotics (Fig. 5). Bacterial density in treatments was significantly higher than, or similar to, that in the negative control. With the presence of antibiotics, the percentage of larval metamorphosis induced by Glu at $1.0 \times 10^{-3} \mathrm{M}$ and Asp from $1.0 \times 10^{-5}$ to $1.0 \times 10^{-3} \mathrm{M}$, respectively, decreased significantly; however, it was still higher than that in the negative control (Fig. 5). The bacterial density in antibiotic treatments was the same as that in the negative control. Both Glu and Asp induced normal metamorphosis in H. elegans.

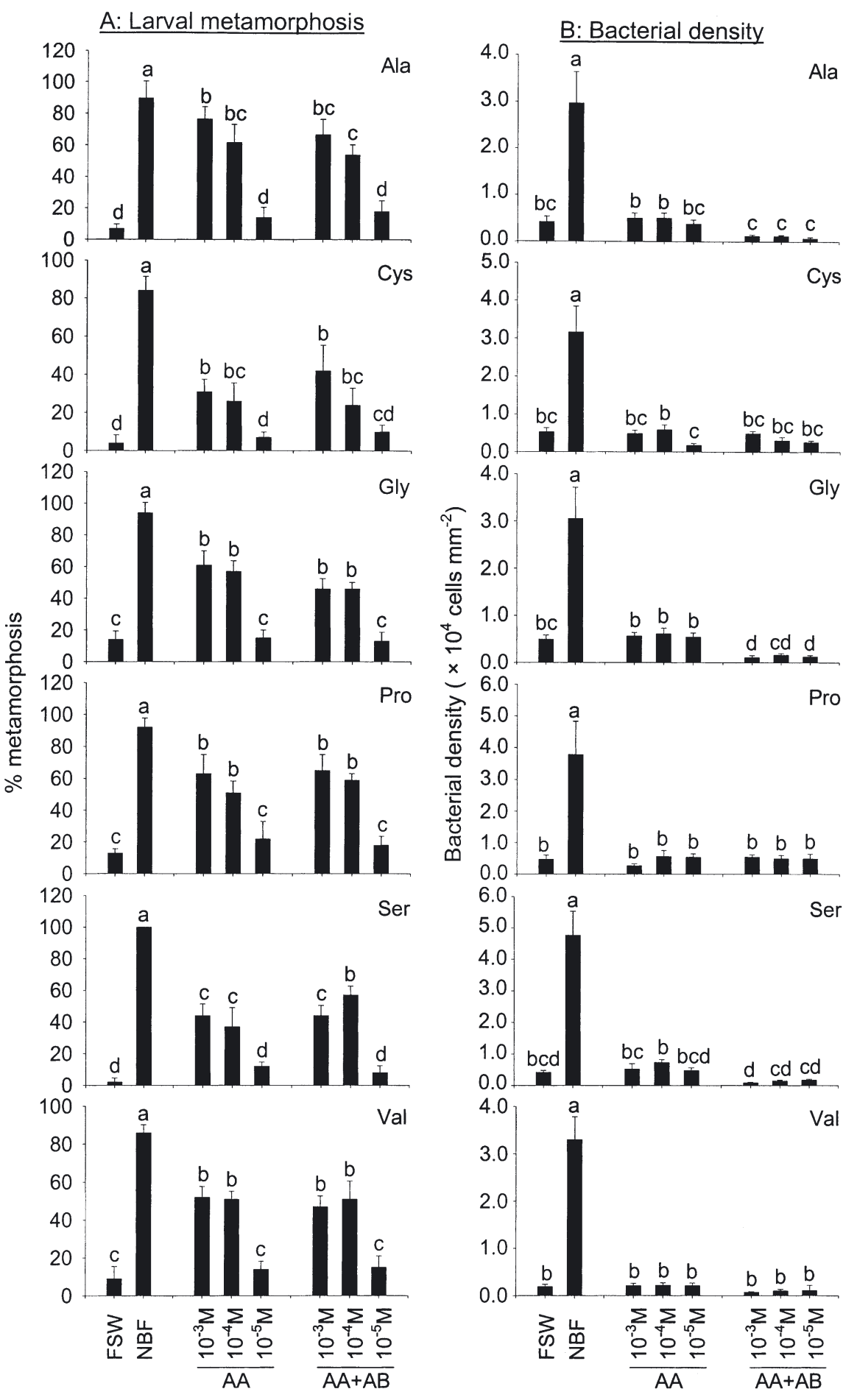

Fig. 2. Hydroides elegans. (A) Mean percentage of metamorphosed larvae in response to 6 amino acids (AA): Ala (alanine), Cys (cysteine), Gly (glycine), Pro (proline), Ser (serine) and Val (valine), in the absence or presence of antibiotics (AB). Data plotted are means $+\mathrm{SD}$ of 5 replicates. (B) Bacterial density in test dishes. Data plotted are means + SD based on counts of 10 fields at $1000 \times$ magnification. Data that are significantly different are indicated by different letters above the bars (1-way ANOVA, $\mathrm{p}<0.05)$. FSW: filtered seawater; NBF: marine natural biofilm 

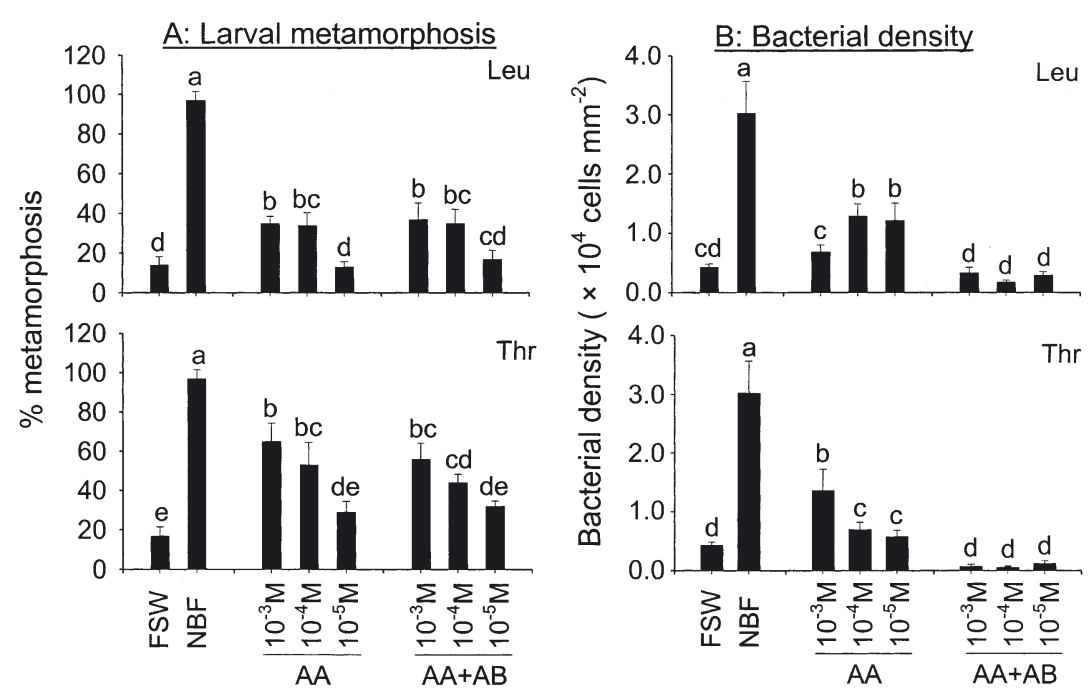

Fig. 3. Hydroides elegans. (A) Mean percentage of metamorphosed larvae in response to 2 amino acids (AA): Leu (leucine) and Thr (threonine) in the absence or presence of antibiotics (AB). Data plotted are means + SD of 5 replicates. (B) Bacterial density in test dishes. Data plotted are means + SD based on counts of 10 fields at $1000 \times$ magnification. Data that are significantly different are indicated by different letters above the bars (1-way ANOVA, p < 0.05). FSW: filtered seawater; NBF: marine natural biofilm

\section{DISCUSSION}

Bryan et al. (1997b, 1998) demonstrated that the homogenate of Hydroides elegans adults and the leachate of the bryozoan Bugula neritina contained a phosis in $H$. elegans. The chemical inducer was isolated and identified as a complex of polar, aliphatic amino acids (Harder \& Qian 1999). The findings of the amino acids as potent natural cues were the result of a series of carefully planned, bioassay-guided isolation and purification process. Nevertheless, these publications have been viewed by some scientists as possible laboratory artifacts, although those scientists ran their bioassays under even less desirable experimental conditions. After reviewing most previous publications on larval bioassays that studied the effects of chemical cues on larval settlement and metamorphosis, we concluded that the roles of bacteria in the bioassay vessels have been speculated, proposed but never vigorously tested. A follow-up study on the effects of amino acids on larval settlement and metamorphosis conducted by our laboratory, indeed, suggested that amino acids might have promoted bacterial film development in chemical inducer for larval attachment and metamor- testing vessels which, in turn, might have triggered larval settlement of $H$. elegans (Beckmann et al. 1999). This allowed us to propose a possible systematic error in the larval bioassay system in potential effects of bacteria on both the chemical cues under consideration and the larvae being tested. However, this proposal was under the 'condition' that the chemical cues could be used by the bacterial film directly, and the cues could have substantial effects on both bacterial abundance and species composition in the film. Hence, we hypothesize a triangular relationship among chemical cues, settling larvae and the biofilm. Since then, in every laboratory bioassay, we have tried to decouple the effects of the chemical cues from those of the bacterial film. Antibiotics were used to eliminate the effects of bacterial development on larval metamorphosis during the bioassay. The present study is the first intensive investigation of the effects of chemimetamorphosis of $H$. elegans with the intention of decoupling the effects of amino acids and bacterial films.

In the present investigation, 9 amino acids were found to be toxic to competent larvae of Hydroides elegans at certain concentrations. It was surprising that almost half the amino acids tested were toxic to $H$. elegans larvae. Even at concentrations as low as $1.0 \times$ $10^{-6} \mathrm{M}$, tryptophan and tyrosine still showed toxic effects. Three aromatic amino acids (phenyalanine, tyrosine and tryptophan) were toxic. Three basic previous studies that did not consider the cal cues (here as amino acids) on larval
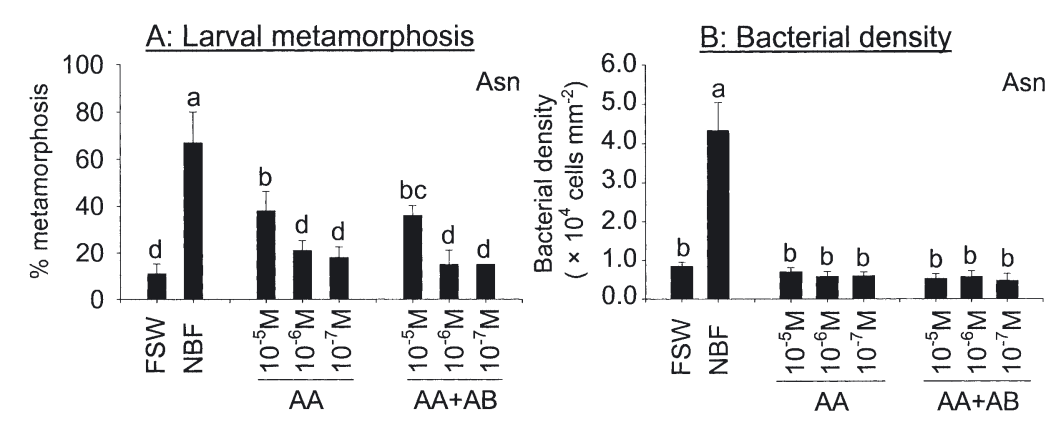

Fig. 4. Hydroides elegans. (A) Mean percentage of metamorphosed larvae in response to Asn (asparagine) in the absence or presence of antibiotics (AB). Data plotted are means $+\mathrm{SD}$ of 5 replicates. (B) Bacterial density in test dishes. Data plotted are means + SD based on counts of 10 fields at $1000 \times$ magnification. Data that are significantly different are indicated by different letters above the bars (1-way ANOVA, $\mathrm{p}<0.05$ ). FSW: filtered seawater; NBF: marine natural biofilm 

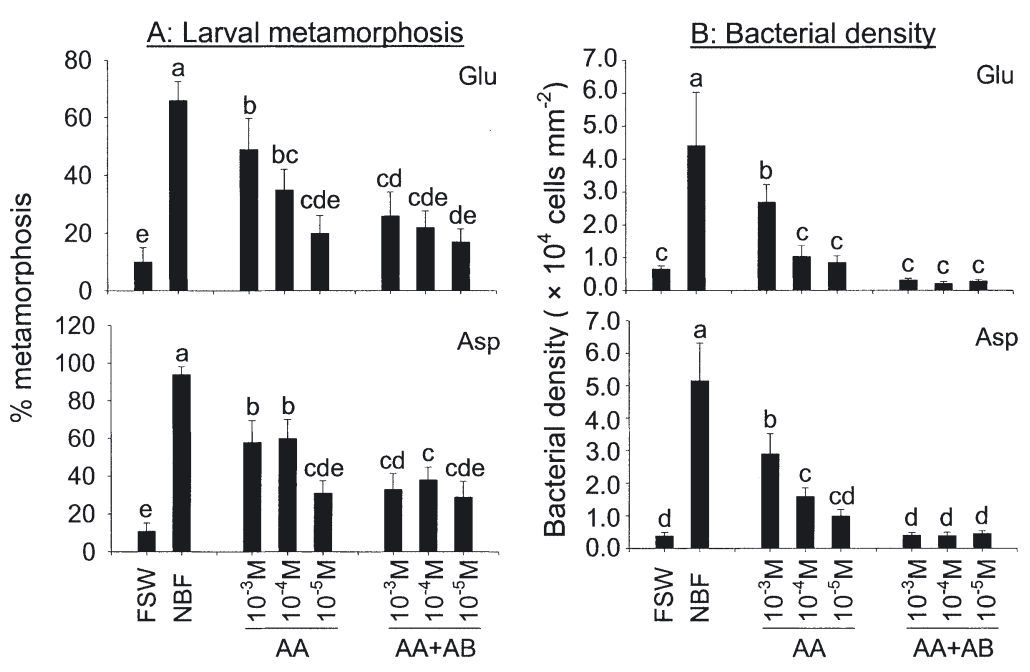

Fig. 5. Hydroides elegans. (A) Mean percentage of metamorphosed larvae in response to 2 amino acids (AA): Glu (glutamic acid) and Asp (aspartic acid) in the absence or presence of antibiotics (AB). Data plotted are means + SD of 5 replicates. (B) Bacterial density in test dishes. Data plotted are means + SD based on counts of 10 fields at $1000 \times$ magnification. Data that are significantly different are indicated by different letters above the bars (1-way ANOVA, $p<0.05$ ). FSW: filtered seawater; NBF: marine natural biofilm

amino acids (histidine, lysine and arginine) were toxic as well. Two acidic amino acids, aspartic acid and glutamic acid, were not toxic; however, their amides asparagine and glutamine were toxic to the larvae. Similarly, Boettcher \& Targett (1998) reported the toxic effects of histidine and leucine on the larvae of the queen conch Strombus gigas at concentrations higher than $1.0 \times 10^{-4} \mathrm{M}$.

The toxicity of amino acids might be related to the side chain. For instance, the only amino acid that did not induce Hydroides elegans larval attachment at any concentration tested was isoleucine, which has the same formula as leucine, but differs in the side-chain primary structure, and showed different effects on larval metamorphosis in $H$. elegans. This result confirms that the biological effect of the amino acid might depend on the side chain.

The results of the larval metamorphosis bioassays showed 11 amino acids were inductive to the larvae of Hydroides elegans at a certain concentration. However, if the bacterial density in the assay dishes and the behavior of the competent larvae in response to these amino acids are compared, the modes of induction can be defined as: (1) the induction of larval metamorphosis by amino acids only, or (2) by both amino acids and bacteria in the dishes. Furthermore, amino acids induced either normal or abnormal metamorphosis.

The effects of amino acids on larval settlement were also investigated in the queen conch Strombus gigas (Boettcher \& Targett 1998) and the barnacle Balanus amphitrite (Mishra \& Kitamura 2000). Similar to most previous studies, in these 2 studies the authors did not consider the possible effects of bacteria on the larval settlement and/or on amino acids during the bioassay. It is impossible to know whether the bacterial film might have affected their findings or not, although we suspect that the bacterial films might have unavoidably developed in their bioassay vessels during their experimental times. Since the larvae of Hydroides elegans settled and metamorphosed well in response to natural biofilm (Lau \& Qian 2001, Harder et al. 2002a,b, Lau et al. 2002, 2003, Lee \& Qian 2003, Lam et al. 2003), it is very important to decouple the potential inductive effect of amino acids investigated from that of bacterial film developed in testing vessels. As a well-recognized fact, it is impossible to develop a bacteria-free larval culture; therefore, bacteria would be introduced when the competent larvae are transferred into the vessels. When the larvae of $H$. elegans were exposed to a mixture of amino acids without antibiotics (Beckmann et al. 1999), the bacterial density in the Petri dishes reached $23732 \pm 4910$ cells $\mathrm{mm}^{-2}$ after $24 \mathrm{~h}$. However, in the present study, it was found that not all amino acids promoted bacterial film development. In the treatments with alanine, cysteine, glycine, proline, serine and valine, regardless of whether antibiotics were added into the Petri dishes or not, the bacterial densities were similar to that in the negative control. This indicates that none of these amino acids promoted bacterial growth significantly in the dishes, even when much higher concentrations of amino acids than those in the study of Beckmann et al. (1999) were used. Therefore, we could assume that the bacterial effects on larval settlement and metamorphosis of $H$. elegans in these treatments were negligible, and the larval metamorphosis induction was solely due to the effects of amino acids.

Asparagine, leucine and threonine, when applied in the absence of antibiotics, promoted bacterial film development, as the bacterial densities in these treatments were significantly higher than those in the negative control. This indicated that bacteria might have utilized these amino acids as a nutrient source. However, in the presence of antibiotics, these amino acids showed the same inductive effects as when without antibotics, suggesting that larval metamorphosis was directly triggered by amino acids. Although the bacterial density was relatively high in the treatments without antibiotics, the bacteria did not show inductive 
effects on larval metamorphosis during the bioassay. Since previous studies demonstrated that many bacterial strains had no inductive effects on the larval metamorphosis of Hydroides elegans (Lau et al. 2002), one may speculate that these amino acids may selectively promote the growth of bacteria that have no direct effects on larval settlement and metamorphosis of $H$. elegans. Further work on the community structure analysis of bacterial biofilms, developed under different treatments of amino acids, will provide insight into the composition of inductive, non-inductive and even inhibitive bacterial strains. This can be achieved by using the most up-to-date DNA fingerprinting techniques on marine biofilm (Qian et al. 2003).

Aspartic acid and glutamic acid also induced larval metamorphosis at certain concentrations without the addition of antibiotics. At inductive concentrations, the bacterial density was significantly higher than that in the negative control. However, when these amino acids were tested in the presence of antibiotics, the percentage of metamorphosis decreased significantly in comparison with treatments without antibiotics, but it was still higher than the negative control. This result suggested that larval metamorphosis might have been the result of a combined effect of amino acid and bacteria in these cases.

Over the last decades, a substantial effort was spent on the investigation of detection mechanisms and the signal transduction pathway involved in larval settlement and metamorphosis processes. However, progress has been very slow. It is believed that larvae have specific receptors to detect inductive chemical cues. Holm et al. (1998) demonstrated that metamorphic-signal transduction in Hydroides elegans is not mediated by a G-protein coupled receptor. The present investigation indicates that amino acid receptors might have been involved in larval settlement and metamorphosis of $H$. elegans. Our ongoing work is targeting towards the receptors that are sensitive to some amino acids, with some encouraging results.

Among the 11 amino acids that were inductive for larval settlement and metamorphosis, 3 amino acids (asparagine, aspartic acid and glutamic acid) induced normal larval metamorphosis, while the other 8 amino acids only induced abnormal metamorphosis (the larvae showed metamorphic changes but did not produce the primary and secondary tubes). The present investigation showed that behavior of the larvae in response to asparagine at certain concentrations was similar to that of the larvae in response to natural biofilm. The larvae started to settle within $1 \mathrm{~h}$ and completed metamorphosis within several hours. This indicates that the larvae might have receptors for asparagine in the periphery of the body, so that they were triggered to metamorphose rapidly. In contrast, the larval metamorphic responses to glutamic and aspartic acid were different to asparagine. After $6 \mathrm{~h}$, only a few larvae began to metamorphose. However, after $24 \mathrm{~h}$, these amino acids showed inductive effects. These 2 amino acids are neurotransmitters and agonists of the glutamate receptors that play an important role in the central nervous system of animals. It is possible that there are no receptors for aspartic acid and glutamic acid in the periphery of the larvae. Therefore, the larvae could not detect these cues in a short period of time. It took some time for the uptake of these amino acids and for the activation of initiation of larval metamorphosis. The most likely receptors activated by these 2 amino acids in larval metamorphosis are glutamate receptors. Our unpublished data on the radio-ligand binding assay showed that the competent larvae of Hydroides elegans indeed had glutamate receptors. However, it will require substantially more experimental evidence to prove the involvement of glutamate receptors in larval settlement and metamorphosis of $H$. elegans.

Other inductive amino acids (alanine, cystein, glycine, proline, serine and valine) induced abnormal larval metamorphosis in Hydroides elegans. This indicated that, although these amino acids triggered larval metamorphosis, the signal transduction pathway involved in this process was only activated partially by these amino acids. The actual mechanism remained unclear. It may also suggest that when the larvae are treated by these amino acids, they require additional cue(s) to complete metamorphosis, indicating that more than one cue may be involved in the completion of larval settlement and metamorphosis, as documented in Harder et al. (2002).

The interaction among settling larvae, amino acids, and marine bacteria can be very complex issue since there have been reports that larvae of marine invertebrates may uptake amino acids and other dissolved organic matter as the nutrient for larval development (Welborn \& Manahan 1990, 1995, Shilling \& Manahan 1994). However, previous studies on the larval uptake of dissolved matter were assessed by monitoring the decline in amino acids (or dissolved organic matter) in the testing vessels over time, and did not investigate biofilm development in their experimental vessels. The potential roles of marine bacteria on amino acid uptake have been totally ignored. Since the development of bacterial film in the testing vessel must have been unavoidable, and bacterial film development could have been enhanced by the addition of amino acids (or dissolved organic matters) in the testing vessel, the declines of amino acids in testing vessels could be due to larval uptake and/or bacterial uptake. Thus, the conclusions drawn in some previous works may become questionable. 
In conclusion, the existing information does not allow us to establish whether or not the gregarious distribution of Hydroides elegans is simply due to larval response to biofilm and/or to physical properties of the surface (keeping in mind that all the surfaces are covered with biofilm), or is due to larval response to conspecific cues, or both. We may argue that the swimming larvae are trapped in the boundary layer (between the substratum surface and water column) when they move down the water column. Within the boundary larvae, the secondary metabolites or chemicals released produced by highly crowded adult/juvenile populations can attract the larvae to settle and metamorphose. The presence of a high concentration of conspecific cues may also alter the bacterial/diatom community structure of the biofilm on the surface, which may in turn act as larval settlement cues. The larvae may complete metamorphosis in response to conspecific cues and/or cues released from the biofilm. The cues produced by the conspecific organisms and biofilm may have synergistic effects on $H$. elegans larvae that may have different receptor systems responding to different cues. In this study, we showed the effects of amino acids on the bacterial abundance of the biofilm, but how amino acids may affect the bacterial species composition in the biofilm still remains unclear. As the composition of bacterial species in a biofilm is at least equally important in affecting its bioactivity, in order to gain a better understanding of how chemical cues, settling larvae, and bacterial film interact, the effects of chemical cues on bacterial community structure need to be closely examined in the near future.

Acknowledgements. We wish to thank D. Hans for productive discussions during the course of this work. This work was supported by a RGC grant (HKUST 6133/99M, HKUST 6100/02M, CA00/01, SC01) to P.-Y.Q.

\section{LITERATURE CITED}

Beckmann M, Harder T, Qian PY (1999) Induction of larval attachment and metamorphosis in the serpulid polychaete Hydroides elegans by dissolved free amino acids: mode of action in laboratory bioassays. Mar Ecol Prog Ser 190: $167-178$

Biggers WJ, Laufer H (1992) Chemical induction of settlement and metamorphosis of Capitella capitata Sp. I (Polychaeta) larvae by juvenile hormone-active compounds. Invert Reprod Dev 22:39-46

Biggers WJ, Laufer H (1996) Detection of juvenile hormoneactive compounds by larvae of the marine annelid Capitella sp. I. Arch Insect Biochem Physiol 32:475-484

Boettcher AA, Targett NM (1998) Role of chemical inducers in larval metamorphosis of queen conch, Strombus gigas Linnaeus: relationship to other marine invertebrate systems. Biol Bull 194:132-142

Bourget E, Harvey M (1998) Spatial analysis of recruitment of marine invertebrates on arborescent substrata. Biofouling
12:45-55

Bryan JP, Rittschof D, Qian PY (1997a) Settlement inhibition of bryozoan larvae by bacterial films and aqueous leathates. Bull Mar Sci 61:849-857

Bryan JP, Qian PY, Kreider JL, Chia FS (1997b) Chemical induction of settlement and metamorphosis of the serpulid polychaete Hydroides elegans. Mar Ecol Prog Ser 146: 81-90

Bryan JP, Kreider JL, Qian PY (1998) Settlement of the serpulid polychaete Hydroides elegans (Haswell) on the arborescent bryozoan Bugula neritina (L.): evidence of chemically mediated relationship. J Exp Mar Biol Ecol 220:171-190

Butman CA (1987) Larval settlement of soft-sediment invertebrates: the spatial scales of pattern explained by active habitat selection and the emerging role of hydrodynamical process. Oceanogr Mar Biol Rev 25:113-165

Butman CA (1990) Sediment-trap experiments on the importance of hydrodynamical processes in distributing settling invertebrate larvae in near-bottom waters. J Exp Mar Biol Ecol 134:37-88

Conover WJ, Iman L (1981) Rank transformations as a bridge between parametric and nonparametric statistics. Am Stat 35:124-129

Crisp DJ (1984) Overview of research on marine invertebrate larvae, 1980-1984: In Costlow JD, Tipper RC (eds) Marine biodeterioration: an interdisciplinary study. Naval Institute Press, Annapolis, MD, p 103-126

Gosselin LA, Qian PY (1997) Juvenile mortality in benthic marine invertebrates. Mar Ecol Prog Ser 146:265-282

Harder T, Qian PY (1999) Induction of larval settlement and metamorphosis in the serpulid polychaete Hydroides elegans by dissolved free amino acids: isolation and identification. Mar Ecol Prog Ser 179:259-271

Harder T, Lam C, Qian PY (2002a) Induction of larval settlement of the polychaete Hydroides elegans (Haswell) by marine biofilms: an investigation of monospecific fouling diatoms as settlement cues. Mar Ecol Prog Ser 229: 105-112

Harder T, Lau SCK, Dahms HU, Qian PY (2002b) Isolation of bacterial metabolites as natural inducers for larval settlement in the marine polychaete Hydroides elegans (Haswell). J Chem Ecol 28(10):2029-2043

Holm ER, Nedved BT, Carpizo-Ituarte, Hadfield MG (1998) Metamorphic-signal transduction in Hydroides elegans (polychaeta: serpulidae) is not mediated by a G protein. Biol Bull 195:21-29

Jensen RA, Morse DE (1990) Chemically induced metamorphosis of polychaete larvae in both the laboratory and the ocean environment. J Chem Ecol 16:911-930

Jensen RA, Morse DE, Petty RL, Hooker N (1990) Artificial induction of larval metamorphosis by free fatty acids. Mar Ecol Prog Ser 67:55-71

Kirchman D, Graham S, Reish D, Mitchell R (1982a) Bacteria induce settlement and metamorphosis of Janua (Dexiospira) brasiliensis Grube (Polychaeta: Spirorbidae). J Exp Mar Biol Ecol 56:153-163

Kirchman D, Graham S, Reish D, Mitchell R (1982b) Lectins may mediate in the settlement and metamorphosis of Janua (Dexiospira) brasiliensis Grube (Polychaeta: Spirorbidae). Mar Biol Lett 3:131-142

Lam KS, Harder T, Qian PY (2003) Induction of larval settlement in the polychaete Hydroides elegans by surface-associated settlement cues of marine benthic diatoms. Mar Ecol Prog Ser 263:83-92

Lau SCK, Qian PY (1997) Phlorotannis and related compounds as larval settlement inhibitors of a tube-building 
polychaete Hydroides elegans (Haswell). Mar Ecol Prog Ser 159:219-227

Lau SCK, Qian PY (2001) Larval settlement in the serpulid polychaete Hydroides elegans (Haswell) in response to bacterial film: an investigation of the nature of putative larval settlement cue. Mar Biol 138:321-328

Lau SCK, Mak KKW, Chen F, Qian PY (2002) Bioactive of bacterial strains isolated from marine biofilms in Hong Kong waters for the induction of larval settlement in the marine polychaete Hydroides elegans. Mar Ecol Prog Ser 226: 301-310

Lau SCK, Harder T, Qian PY (2003) Induction of larval settlement in the serpulid polychaete Hydroides elegans (Haswell): role of bacterial extracellular polymers. Biofouling 19:197-204

Lee OO, Qian PY (2003) The chemical control of bacterial epiosis and larval settlement of Hydroides elegans in the red sponge Mycale adherens. Biofouling 19(Suppl) $171-180$

Lemire M, Bourget E (1996) Substratum heterogeneity and complexity influence micro-habitat selection of Balanus sp. and Tubularia crocea larvae. Mar Ecol Prog Ser 135: $77-87$

Maki JS, Rittschof D, Schmidt AR, Snyder AG, Michell R (1989) Factors controlling attachment of bryozoan larvae: a comparison of bacterial films and unfilmed surface. Biol Bull 177:295-302

Mishra JK, Kitamura H (2000) The effect of amino acids on larval settlement of the banacle, Balanus amphitrite Darwin. Biofouling 14(4):299-303

Pawlik JR (1986) Chemical induction of larval settlement and metamorphosis in the reef-building tube worm Phragmatopoma California (Sabellariidae: Polychaeta). Mar Biol 91:59-68

Pawlik JR (1990) Natural and artificial induction of metamorphosis of Phragmatopoma lapidosa California (Polychaeta: Sabellariidae), with a critical look at the effects of bioactive compounds on marine invertebrate larvae. Bull Mar Sci 46:512-536

Pawlik JR (1992) Chemical ecology of the settlement of benthic marine invertebrates. Oceanogr Mar Biol Annu Rev 30:273-335

Pawlik JR, Butman CA (1993) Settlement of a marine tube worm as a function of current velocity: interacting effects of hydrodynamics and behavior. Limnol Oceanogr 38: 1730-1740

Pawlik JR, Faulkner DJ (1986) Specific free fatty acids induce larval settlement and metamorphosis of the reef-building tube worm Phragmatopoma California (Fewkes). J Exp Mar Biol Ecol 102:301-310

Pawlik JR, Faulkner DJ (1988) The gregarious settlement of Sabellariid polychaetes: new perspectives on chemical cues. In: Thompson MF, Sarojini R, Nagabhushanam R (eds) Marine biodeterioration: advanced techniques applicable to Indian Ocean. Oxford \& IBH Publishing, New Dehli, p 475-487

Pechenik JA, Qian PY (1998) Onset and maintenance of metamorphic competence in the marine polychaete Hydroides elegans Haswell in reponse to three chemical cues. J Exp Mar Biol Ecol 226:51-74

Pechenik JA, Hadfield MG, Eyster LS (1995) Assessing

Editorial responsibility: Otto Kinne (Editor), Oldendorf/Luhe, Germany whether larvae of the opisthobranch gastropod Phestilla sibogae Bergh become responsive to three chemical cues at the same age. J Exp Mar Biol Ecol 191:1-17

Qian PY (1999) Larval settlement of polychaetes. Hydrobiologia 402:239-253

Qian PY, Pechenik JA (1998) Effects of larval starvation and delayed metamorphosis on juvenile survival and growth of the tube-dwelling polychaete Hydroides elegans. J Exp Mar Biol Ecol 227:169-185

Qian PY, Thiyagarajan V, Lau SCK, Cheung SCK (2003) Relationship between bacterial community profile and the attachment of acorn barnacle Balanus amphitrite Darwin. Aquat Microb Ecol 33:225-237

Qiu JW, Qian PY (1997) Combined effects of salinity, temperature and food concentration on the early development of the polychaete Hydroides elegans (Haswell, 1883). Mar Ecol Prog Ser 152:79-88

Rittschof D (1997) Fouling and natural products as antifoulants. In: Fingerman M, Nagabhushanam R, Thompson MF (eds) Recent advances in marine biotechnology, Vol 3. Science Publishers, Enfield, NH, p 245-257

Rodriguez SR, Ojeda FP, Inestrosa NC (1993) Settlement of benthic marine invertebrates. Mar Ecol Prog Ser 97: 193-207

Shapiro SS, Wilk MB (1965) An analysis of variance test for normality (complete samples). Biometrika 52:591-611

Shilling FM, DT Manahan (1994) Energy metabolism and amino acid transport during early development of antarctic and temperate echinoderms. Biol Bull 187:398-407

Snerlgrove PVR, Butman CA, Grassle JP (1993) Hydrodynamic enhancement of larval settlement in the bivalve Mulinia lateralis (Say) and polychaete Capitella sp. I in microdepositional environments. J Exp Mar Biol Ecol 168: 71-109

Thiebaut E, Dauvin JC, Wang ZX (1996) Tidal transport of Pectinaria koreni postlarvae (Annelida: Polychaeta) in the Bay of Seine (eastern English Channel). Mar Ecol Prog Ser 138:63-70

Thorson G (1950) Reproductive and larval ecology of marine bottom invertebrates. Biol Rev 25:1-45

Toonen RJ, Pawlik JR (1994) Foundations of gregariousness. Nature 370:511-512

Walters LJ, Hadfield MG, Carmen KA del (1997) The importance of larval choice and hydrodynamics in creating aggregations of Hydroides elegans (Polychaete: Serpulidae). Invert Biol 116:102-114

Welborn JR, Manahan DT (1990) Direct measurements of sugar uptake from seawater into molluscan larvae. Mar Ecol Prog Ser 65:233-239

Welborn JR, Manahan DT (1995) Taurine metabolism in larvae of marine invertebrate mollusks (Bivalvia, Gastropoda). J Exp Biol 198:1791-1799

Wisely B (1958) The development and settling of a serpulid worm, Hydroides norvegica Gunnerus (Polychaeta). Aust J Mar Freshw Res 9:351-361

Yool AJ, Grau SM, Hadfield MG, Jensen RA, Markell DA, Morse DE (1986) Excess potassium induces larval metamorphosis of four marine invertebrate species. Biol Bull 170:255-266

Zar JH (1996) Biostatistical analysis, 3rd edn. Prentice-Hall, Upper Saddle River, NJ

Submitted: July 16, 2003; Accepted: November 4, 2003

Proofs received from author(s): February 5, 2004 